\title{
The Good, the Bad and the Ugly: Risk, Uncertainty and Decision-Making by Victorian Fishers
}

\author{
Peter D. Dwyer and Monica Minnegal \\ The University of Melbourne
}

\section{Introduction}

In pursuing their livelihood, and in a variety of overlapping contexts, commercial fishers must rely on information that is often incomplete. To fish successfully requires not only careful judgement of variable weather and water conditions and the likely movement of fish, but may entail exploration of new or less well known grounds. Fishers must also weigh up the fluctuating prices on offer for different species and qualities of fish, and make decisions on the basis of the actual or likely behaviour of other fishers with whom they cooperate or compete to supply the market. And they must negotiate the shifting regulations and advice that emanates from those who are charged with managing fisheries.

In this article we explore decision-making among ocean-going, commercial fishers of Lakes Entrance, in the state of Victoria, southeast Australia. ${ }^{1}$ We consider three idealized contexts in which fishers make decisions on the basis of incomplete information. These are, first, the physical and biological environment that they encounter when fishing; secondly, the socioeconomic environment as represented by both middle-men (buyers, processors) who move fish from points of landing to retail outlets and other fishers whose actions may affect disposal options and prices; and, thirdly, the environment of management as represented primarily by decisions and edicts emanating from State and Commonwealth (Federal) Government authorities charged with managing fisheries. We explore each of these contexts with reference to 'risk' and 'uncertainty'. The former term covers situations in which relevant actors are able to assess the likelihood that particular events may occur, and the latter covers situations in which no such assessment is possible (Cashdan 1990:2-3; Knight 1933). We recognise that fishers may, in different circumstances and for reasons of their own, construct the same context as being either risky or uncertain. Within the frame of these constructions we identify the general form of expected responses by fishers and discuss their actual responses to particular circumstances.

At the close of the article we turn to more general considerations of 'risk' and 'risk society' as these topics have been discussed by theorists of late modernity (Beck 1999; Giddens 1991, 1999). We propose that fishers, like many other decision-makers, simultaneously experience contexts of remarkably different sorts - contexts that influence their attitudes and understandings with respect to certainty, social identity, personhood, agency and temporal orientation - with the outcomes that their life-worlds must be understood as complex, multidimensional and potentially fluid. Our argument here serves as an anthropological challenge to the implication, found in some of the work of Giddens and Beck, of an historical trajectory from a "pre-modern" to a "late modern" state in which, at any time, a particular society assumes a specific condition with respect to "modernity"; that is, we dispute the essentializing and universalizing tenor implicit in the work of these social theorists (Caplan 2000a). In developing this argument we outline a comparative frame for future anthropological analyses of multidimensional life-worlds.

Different methods are available for the analysis of decision-making in contexts of incomplete information. In broad terms a contrast may be drawn between scientific ecological approaches and ethno-ecological approaches; approaches that, in earlier anthropological literature, were referred to as 'etic' and 'emic' respectively (Harris 1968:568-604; Pike 1954:8). In the present article our emphasis is with the latter. At the same time, however, we intend that our ethno-ecological approach, in which the perspective of fishers is prioritized, does not do a disservice to potential quantitative analyses that might, for example, draw upon game theory (e.g. Davenport 1970). Indeed, we note that each of the

1. Earlier versions of this article were presented to the Anthropology Seminar Program, The University of Melbourne, Australia and the Department of Anthropology and the Durrell Institute of Conservation Ecology, University of Kent at Canterbury, UK. We thank participants at those seminars for their comments and Roger Just for his invitation to present a paper at the latter venue. We thank the fishers of Lakes Entrance whose lives we have intruded upon and report, 'Ned' and 'Rule' for checking particular sections of this article, Simone Blair and Tanya King for many conversations about fishing and fishers, and Simon Batterbury and two referees for useful comments on the manuscript. Our research has been supported by grants from The Australian Research Council.

Dwyer pddwyer@unimelb.edu.au, Minnegal mmam@unimelb.edu.au 
three categories of 'games' recognised by economists and ecologists is commonly used to analyse decision-making in one of the generic contexts of interest to us (Barth 1959; Hawkes 1992; Kahneman and Tversky 2000; Smith 2000). Thus, 'games against nature' explore decision-making in contexts of the physical and biological environment; 'n-person games' explore decision-making in contexts of social interaction; and 'games of uncertainty' explore decision-making in contexts in which a player either does not know what outcomes will follow from his decisions or cannot intuitively assign probabilities to those outcomes (Coleman 1995; Dugatkin 1996; Maynard-Smith 1982). Decisionmaking in the frame of these three categories of games may be understood as entailing the management of risk or uncertainty by skill, cunning or recklessness respectively; by strategies that, in our title, we have represented as 'the good, the bad and the ugly' (Coleman 1995:32). ${ }^{2}$ In this paper, our examples are informed by understandings drawn from game theory. They are not, however, presented within that formal framework. But before turning to the fishers themselves it is necessary to first consider the awkward concepts of risk and uncertainty in more detail.

\section{Risk and Uncertainty} uncertainty:

In 1921, the economist Frank Knight made the following distinction between risk and

Uncertainty must be taken in a sense radically distinct from the familiar notion of Risk. The term 'risk', as loosely used ... covers two things which are categorically different. 'Risk' means in some cases a quantity susceptible of measurement, while at other times [it] is something distinctly not of this character. A measurable uncertainty, or 'risk' proper, is so far different from an unmeasurable one that it is not in effect an uncertainty at all (1933:19-20, paraphrased; see also Keynes 1937).

Risk may be quantified; uncertainty cannot be quantified. Risk applies to contexts in which actors are able to assess the likelihood that certain events will occur. Uncertainty applies to contexts in which no such assessment is possible. To speak of 'a calculated risk' is to refer to 'risk' in the narrow sense that, following Knight, we adopt in this article. And, of course, that particular colloquialism alerts us to the fact that 'risk' is not merely or always constraining; risk may provide opportunities to act or not act in particular ways (Hawkes 1990; Kaplan et al. 1990; Ludvico 1991; Smith 1991). ${ }^{3}$

Not all writers accept this distinction. For example, Giddens (1998:104-105; see also Beck 1999:112) wrote:

Frank Knight made the distinction between risk and uncertainty. He argued that risk concerns future probabilities which can be calculated, uncertainty, ones that cannot be. But that distinction doesn't hold water: there are too many fuzzy areas in the middle. There isn't a tight distinction between risk and uncertainty.

In other writing, Giddens continued to assert that risk and uncertainty cannot be distinguished but proposed a distinction between "two types of risk" (1999:20-35). Thus, on the one hand, he referred to

2. Though directing attention to connections between the analyses in this paper and other analyses that might be based in game theory we are not committed to the formal assumptions of rational choice models. Rather we follow Colman and Wilson (1997:25) who considered game theoretical models to be abstract idealizations of 'phenomena' and argued that the extent to which a model 'corresponds to the original phenomenon is always a matter of judgement and empirical evidence'. The rationality assumed by game theoretical models is inherent in the formal structure of those models, but is not necessarily inherent in actors who confront and must resolve situations that are constructed in this way. That is, for both analysts and actors there may be a disjunction between the rules of the game (logical logic) and adjustments made in the light of those rules (practical logic; Bourdieu 1990). To this extent, the anthropological value of game theoretical analysis resides in its potential to reveal the logical structure of particular strategic interactions, to detect similarities and differences among apparently related strategic interactions, and to make explicit the paradoxes, opportunities and uncertainties that confront, and must be resolved by, actors who engage in those interactions (Dwyer 2000). Stated simply, game theoretical analysis may reveal the structure of problems that people are called upon to solve.

3. Our formal take on 'risk' differs from that of theorists of 'vulnerability' who, in offering the equation 'vulnerability x hazard' equals 'risk', are aligned with the colloquial sense of 'risk' as 'exposure to mischance or peril' (Blakie et al. 1994; Shorter Oxford English Dictionary). Under this understanding 'risk' is not understood as providing opportunities or rewards (Adams 1999). 
"external risk" which is experienced as coming from "the fixities of tradition or nature" and is amenable to calculation or "actuarial prediction" and, on the other, to "manufactured risk" which is created by the impacts of "knowledge upon the world" and is not amenable to calculation (1999:2628). In "situations of manufactured risk ... we simply don't know what the level of risk is, and in many cases we won't know for sure until it is too late" (1999:28; see also Beck's notion of "fabricated uncertainty" [1999:19] and Adams" notion of "virtual risk" [1999]). The distinction Giddens made here is, surely, in keeping with Knight's understanding of the difference between risk and uncertainty. Indeed, in their respective diagnoses of late or reflexive modernity the substantive examples considered by both Giddens and Beck nearly always concern uncertainty - 'manufactured risk' - and not risk sensu strictu; their focus is with biotechnology, nuclear warfare, climate change, collapse of economies, terrorism and so forth. As Beck (1999:4) noted, these sorts of events cannot be covered by private insurance. They cannot be covered, of course, for the simple reason that insurance brokers are unable to assign probabilities to their occurrence.

Though we consider that Giddens and Beck are formally wrong to conflate definitions of risk and uncertainty we accept that problems remain in separating these notions. The problems concern scale, the position of particular actors vis-a-vis particular situations and the potential for strategic interpretation (e.g. Douglas and Wildavsky 1982). For example, the impacts of new technologies such as genetic engineering cannot be assigned probabilities until they have been in operation for sufficiently long that quantitative assessments can be made on the basis of a long run of data. Thus, an increase in knowledge - a change of perceptual scale - may reposition a potential event from the domain of the uncertain to that of risk. And this means, of course, that from the perspective of different actors the same situation may be experienced as uncertain or as risky according to their current understanding of potential impacts. ${ }^{4}$ To the extent that actors will make different sorts of decisions in contexts of risk and uncertainty this distinction is crucially important. Finally, the potential exists for actors to manipulate outcomes by asserting that risky situations were or are uncertain and vice versa. This may sometimes be the case with drought in Australia. The Australian climate is extremely variable. Stocking rates on pasture could be set in relation to knowledge of this variation. The cost to graziers would be loss of potential profit in favourable years. But the public perception promoted by the grazing industry is of uncertainty and not of risk. In this way industry can pursue maximum profit in good years and government relief in bad years. If they acknowledged that their ventures were risky rather than uncertain then they themselves could be blamed for losses experienced during drought. ${ }^{5}$

The preceding comments direct attention to the fact that when decisions are made in contexts of risk then the decision-makers are likely to be oriented to the past or, as Giddens expressed it, to "the fixities of tradition or nature". They are likely to draw on past experiences in arriving at their decisions. But when decisions are made in contexts of uncertainty past experience is of little help. Decisionmakers are likely to be oriented to the future, to reach decisions on the basis of judgements and guesses about what might be the case or what might be desirable. While those judgements, as Adams (1999: 1) has argued, may be based on "preestablished beliefs, convictions, and superstitions" derived from other domains of action, their applicability remains a matter of hope, not expectation. The contrast we draw here implies that contexts of risk will often be local while contexts of uncertainty will often be global. We shall return to these matters later.

4. We stress that actors' perceptions, or constructions, of particular environments as entailing risk or uncertainty are not givens but must be assessed on a case by case basis. Not all commercial fishers will experience the biophysical and management environments in the ways that they are experienced by fishers at Lakes Entrance. Indeed, in different geographic areas, or at different historical moments in the development of a fishery, fishers themselves may experience the biophysical environment as either risky or uncertain. The ways in which actors arrive at decisions will be grounded in those understandings. We might reinforce our position in this paper by noting that while fishers may experience the biophysical environment as one of risk and the management environment as one of uncertainty, managers may experience the former as uncertain while experiencing their interactions with fishers as risky. That is, different sets of actors, even at the same time and in the same place, may have different understandings of the same environment (King 2005).

5. A cattle breeder of northwest New South Wales was quoted as follows: "What happens in a drought, is your cattle are in good condition and you hang on, hoping it's going to break. When it doesn't ... you'd like to reduce your stock numbers, but the cattle are worth almost nothing" (The Australian September 23, 2002:1). The comment implies an appreciation that drought could be interpreted in terms of risk rather than of uncertainty. 


\section{The Lakes Entrance Fishing Fleet}

Lakes Entrance is a coastal town, 275 kilometres east of Melbourne, with a resident population, in 2003, of about 5000 people. It is at the eastern end of 400 square kilometres of interconnected lakes, the Gippsland Lakes, which are used by both recreational fishers and 19 small-scale commercial fishers who target a variety of fin fish (Figure 1). Fishing and tourism are major industries and, at the peak of the tourist season, the population may swell to 30,000 or more. We have visited Lakes Entrance on 15 occasions, varying from eight days to five months, between June 2000 and February 2004. On each visit we conducted daily censuses of the number and identity of boats in port, of the fishing gear they carried and of their fishing activities. We observed changes in boat ownership and of crew and, as opportunities arose, attended meetings and talked with fishers in informal or formal contexts. The present paper represents part of a larger study of the ethnography of fishing communities at Lakes Entrance and elsewhere in Victoria (Dwyer et al. 2003; Minnegal et al. 2003; see also King 2005).

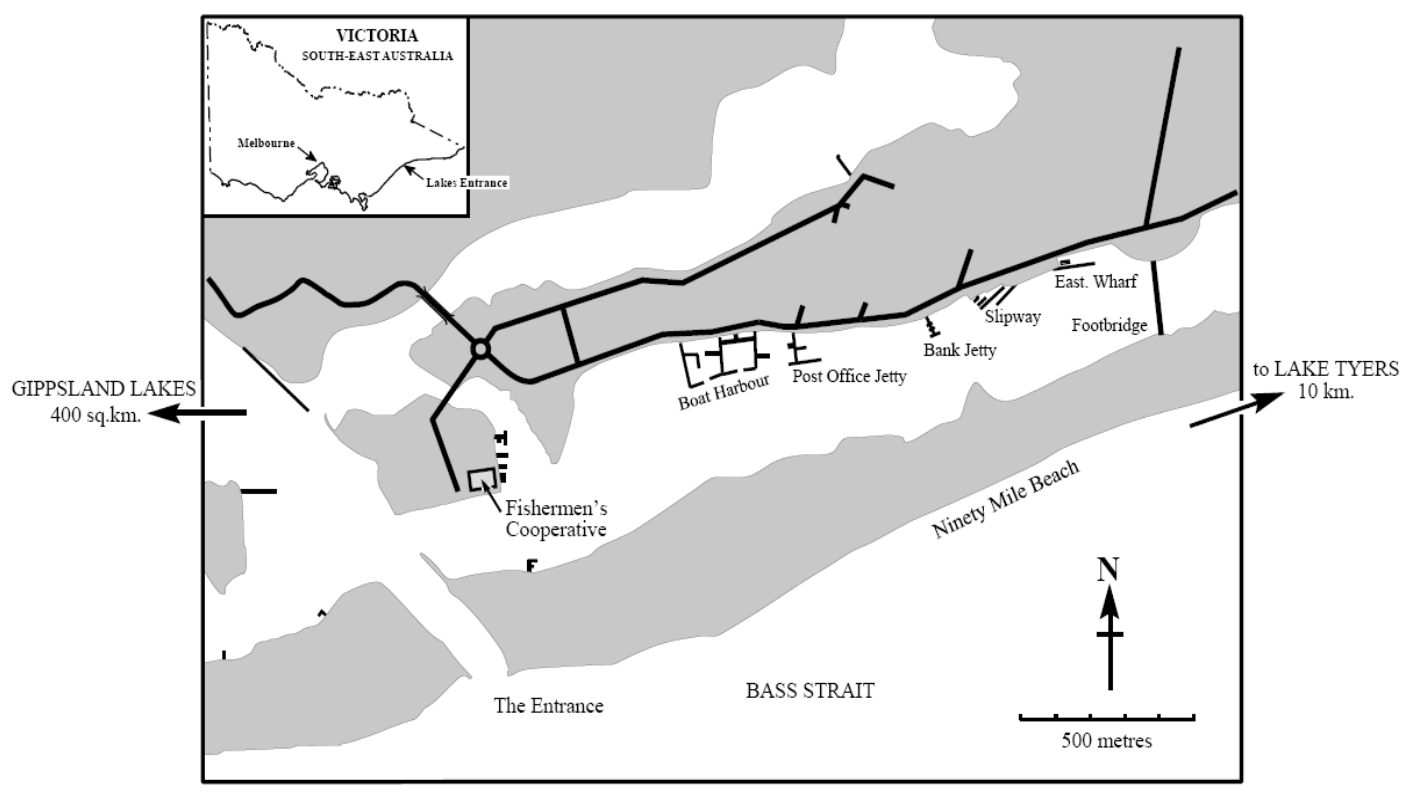

Figure 1. Lakes Entrance and environs.

Between 2000 and 2004 the ocean-going fishing fleet at Lakes Entrance has included from 60 to 75 working boats varying in length from 10 to 25 metres. Figure 2 summarizes composition of the fleet through the year according to the fishing gear that they carry. The fleet includes a few lobster boats, about ten shark boats fitted with gill nets, just under 20 Danish seiners, about six otter board trawlers, a few boats rigged for squid and variable numbers of inshore trawlers, scallop boats and others. ${ }^{6}$ The most noticeable seasonal change is the shift between inshore trawlers which are common in the first half of the year and scallop boats which are most common in the latter half of the year. This shift is a consequence both of local boats changing gear on a seasonal basis and of extralimital boats arriving to fish from Lakes Entrance in either the prawn or the scallop season. The remaining boats, grouped

6. Danish seine fishing gear is light relative to the gear used by larger otter board trawlers. The crew pays out about 1200 metres of rope, attach the wings and cod end of the net and, paying out another 1200 metres of rope, return the boat to its starting place. The ropes have been arranged to form either a triangle or diamond shape. The net is now winched in as the boat steams slowly ahead. Mud or sand raised by the tightening ropes herd fish toward and into the net. 
under 'other' on Figure 2, comprise a purse seiner, one or more long liners, drop liners and trappers these are not always present - and a boat that has been sometimes rigged to catch live, reef-dwelling banded morwong (Cheilodactylus spectabilis).

Not all ocean-going boats at Lakes Entrance are using all of their gear at any one time. In Figure 3 we summarize the targets of boats that fished in any particular month. Lobster fishing commences in November and fades away through the winter months. This pattern is an outcome of management constraints that entail closure of the fishery for a few months late in each year, prohibitions on taking female lobsters through winter months and quotas which some fishers can fill within a few months of commencing fishing. The patterns for shark, Danish seine and otter-board fishing are relatively consistent through the year. In these fisheries most of the variation seen in Figure 3 is an outcome of sampling problems rather than indicative of temporal variation in fishing behaviour. ${ }^{7}$ Local otter-board trawlers may fish almost continually. Financial constraints of high investment and overheads are major influences. The largest trawlers work with two crews, returning to port, off-loading their catch, repairing nets and other gear, changing crew and returning to sea.

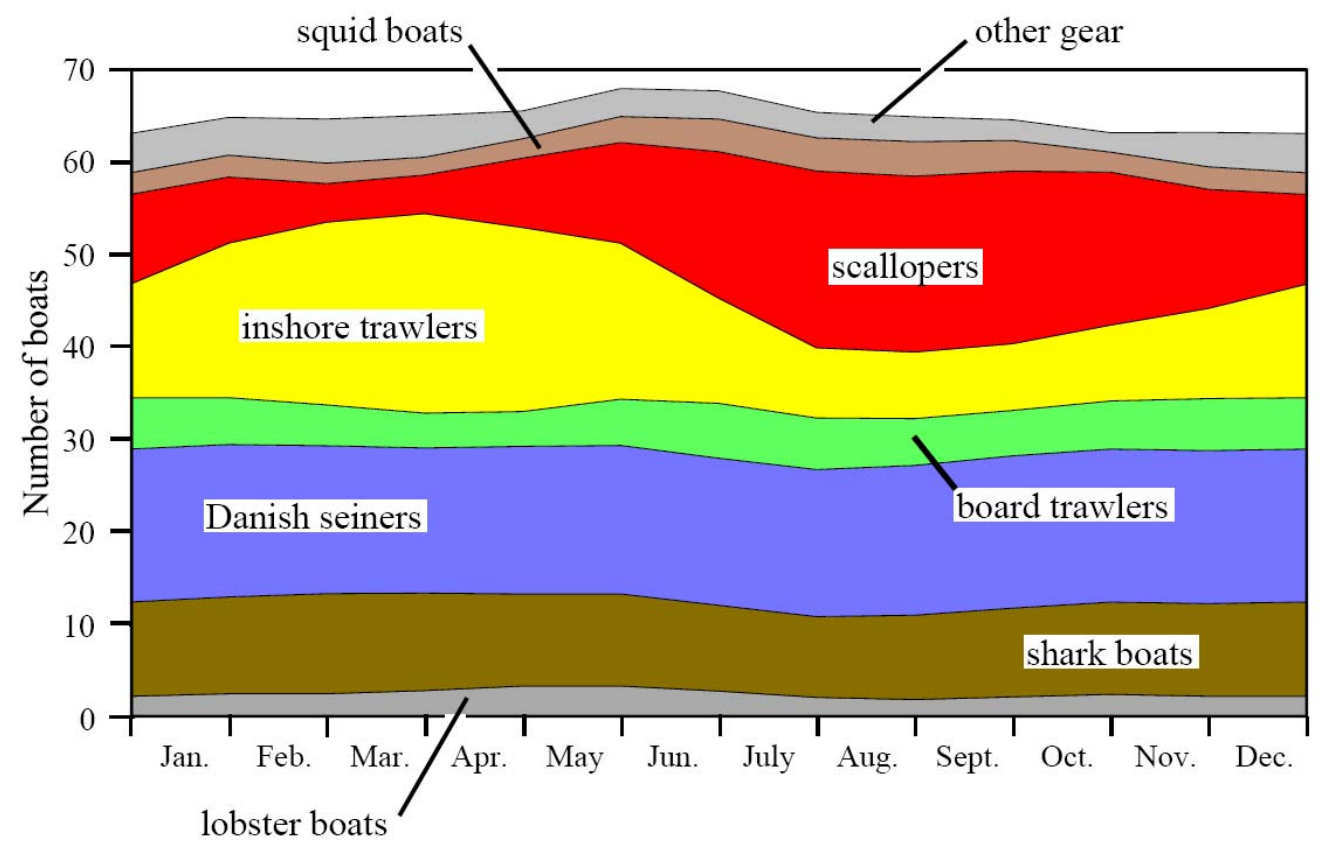

Figure 2. The composition of the ocean-going fishing fleet at Lakes Entrance. Boats are distinguished on the basis of gear that they carry. Data are based on daily surveys of boats and their fishing gear on all visits to Lakes Entrance from June-July 2000 to February 2004. Boats that were simultaneously rigged with two or more types of gear are allocated proportionately to different categories and records from the same month in different years are averaged. Records are smoothed across months (January and November) without data.

The primary seasonal change shown in Figure 3 is with boats that target prawns (Metapenaeus) and Balmain bugs (Ibacus) on the one hand and those that target scallops (Pecten and Chlamys) on the other. As noted above many of these are the same boats, targeting prawns when these are available and switching to scallops when, or if, appropriate beds are opened by State and Commonwealth managers. Since 2000, no boats have targeted squid close to Lakes Entrance though in both 2001 and 2003 when squid availability and prices were judged to be satisfactory some boats from Lakes Entrance moved to

7. Sampling problems result from the facts that visits to Lakes Entrance were of different duration and weather conditions and phase of moon influenced fishing activity. 
Portland, $560 \mathrm{~km}$ to the west, for the autumn and early winter season. Finally, the boats grouped as 'other' on Figure 2 variously target anchovy, pilchard and Australian salmon (with purse seine nets), shark and pink ling (by drop line, long line or trap rather than gill net) and live banded morwong (with small gill nets set over reefs).

About 65 percent of boats in the Lakes Entrance fleet are run by owner-operators. In most of the remaining cases an older owner has given up fishing and hired a skipper who, in some cases, is his son. None of the current owner-skippers is female. ${ }^{8}$ Nearly 90 percent of owners have a single boat only. The location of Lakes Entrance lends itself to a variety of fishing strategies and to many opportunities for switching between strategies. These characteristics have contributed to the survival of the fleet, to complex patterns of cooperation and competition within and between fisheries and to often difficult interactions with management. The actions of management are understood by many fishers to penalize those who diversify in the interests of sustaining personal economic viability and a life-style to which they are committed (Minnegal et al. 2003; see also Hilborn et al. 2001).

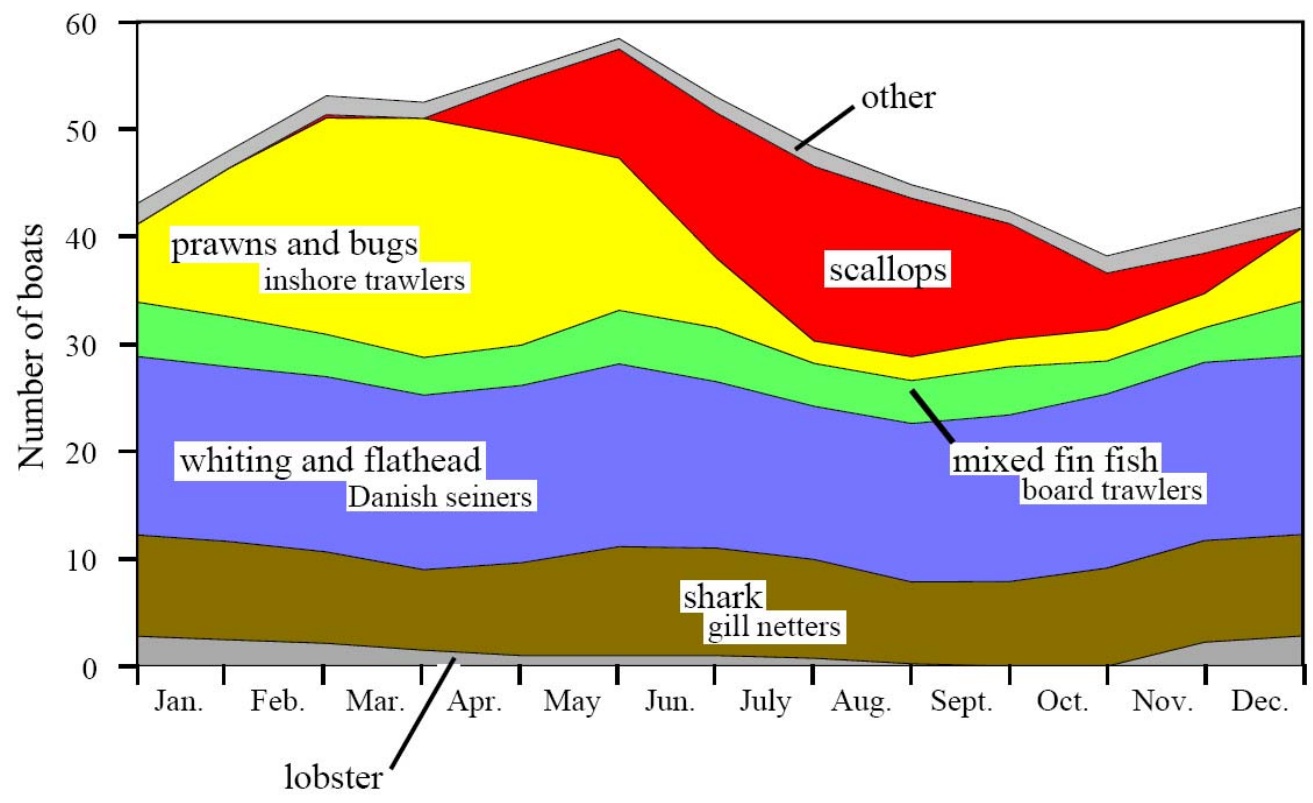

Figure 3. Seasonal variation in primary targets of the ocean-going fishing fleet at Lakes Entrance. Data are based on surveys of fishing activity on all visits to Lakes Entrance from September 2000 to February 2004 with the exception of July 2001 when weather conditions during the survey period kept most boats in port. We do not include data from June-July 2000 because we had not yet learned to accurately assess fishing activity. Boats that switched target within a survey period are allocated proportionately to different categories and records from the same month in different years are averaged. Records are smoothed across months (January and November) without data.

We turn now to the behaviour of fishers and to ways in which their decisions are influenced by different contexts. We commence with an example of decision-making in the context of the physical and biological environment of Bass Strait, the region of ocean immediately south of Lakes Entrance and the primary fishing grounds of commercial fishers based at that port.

8. In Victoria most, but not all, fishers are in fact male and, in this paper, this is how we identify them. The irony in our usage is that it is the supposedly gender-neutral word 'fisher' that does a disservice to the ways in which the people we know speak. Most of those who fish commercially, irrespective of gender, regard themselves and are regarded by others as 'fishermen'. 


\section{Decision-making in the Physical and Biological Environment}

At Lakes Entrance the commercial prawn season commences in the summer months of December or January, though in some years availability of prawns is poor and little fishing occurs. The season continues until the waters of the Gippsland Lakes and Bass Strait cool, the accessibility of prawns declines, and fishers turn to other targets. This may be as early as April or as late as June. In the waters of Bass Strait prawns are least available and of lowest quality for a few days before, and a week or more after, full moon. Many are moulting; they are likely to have soft shells, be more difficult to catch and are less marketable. At these times, therefore, there is a marked reduction in the number of prawn boats that fish (Figure 4). There are, of course, other influences on fishing activity. Overcast conditions reduce the negative effect of full moon on catch rates, strong winds discourage fishing and the condition of the bar at the artificial entrance which provides access to and from the ocean may delay or prevent boats from entering or exiting the port. Some combinations of wind, tide and outflow result in a substantial build up of sand that renders the bar dangerous to shipping until conditions improve and the government dredge is able to attend to the problem.

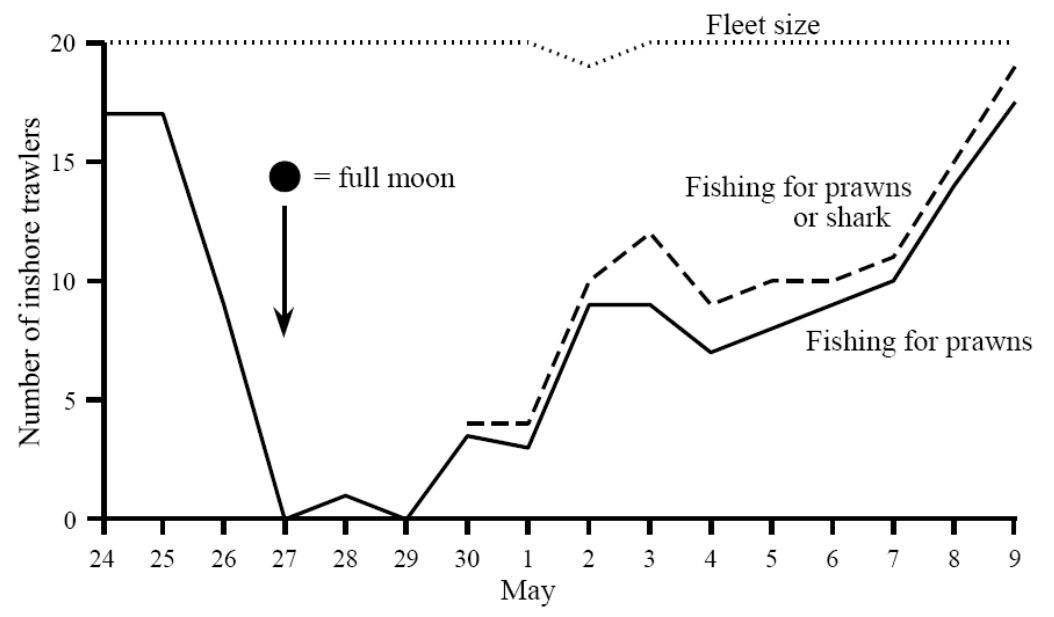

Figure 4. Fishing activity by inshore trawlers in late April and early May 2000. A marked reduction in effort immediately before and following full moon is evident. The figure shows boats that fished for prawns only and those that fished for both prawns and shark. The slight change in fleet size in early May is the result of one boat being temporarily out of commission.

On April 29, 2002 the bar had been difficult to negotiate for several days and few boats were either leaving from or arriving at Lakes Entrance. That night, however, four inshore trawlers ventured outside and fished to the east of the entrance. The next morning they were unable to return to port. Because this was only three days after full moon their catch included a high proportion of soft-shelled prawns. The day was warm, ice melted, the condition of the prawns deteriorated and the entire catch was discarded at sea. One of the four boats was rigged with both inshore trawl and shark gear. Realizing that he would be delayed by the bar, and that his prawns would be wasted, the skipper 'Rule' - a pseudonym - steamed west, set but did not haul his shark net, returned to the entrance and joined the other boats when they made their run across the bar at midday on a high tide. He remained in port for about four hours before returning to sea, hauling the shark net and continuing to fish for shark through the rest of that night.

On this occasion, Rule's shark-fishing behaviour confounded our expectations. Shark-fishing trips are usually relatively long, averaging about seven days $(\bar{x}=7.2 \pm 2.1$ days, range $=4$ to $11 ; n=$ 44 trips) and nets are not usually left unattended in the water for long periods. However, once Rule had altered his behaviour he continued the new pattern. Through the next two weeks he fished for shark in the same way and in the same general area on eight occasions; that is, he left port, headed west, fished 
for some hours, returned to port with his net left in the water and departed to haul it later the same day. On these occasions he did not fish for prawns. ${ }^{9}$

Rule could fish for shark in this way only because he shot his net within a region of cold water. Had the water been warm the flesh of captured sharks that had been left for more than eight hours would have deteriorated and the animals could not have been sold. And, further, the activity of 'sea lice' (isopods) which may rapidly damage captured sharks is reduced in daylight hours and in cold water. But once Rule had initiated a strategy of 'brief and near' fishing some others followed suit. The two other inshore trawlers that were simultaneously rigged for shark spent at least 10 days fishing in this way through the first two weeks of May though on some of those days they targeted both shark and prawn, trawling for the latter after setting and leaving their shark net (Figure 4). By fishing in this way they could observe returns of prawns achieved by other fishers and judge whether and when it was worthwhile switching between targets. On a few nights in this period they targeted prawns only. Few of six dedicated shark boats - those that carried no alternative gear - switched strategy. In the first two weeks of May only three of 40 fishing days by these boats were 'brief and near'. By late May returns from prawns were poor. One of the three mixed-gear boats abandoned prawns and fished for shark in the conventional way, one replaced inshore trawl gear with scallop gear and the third ceased fishing.

The preceding example illustrates several ways in which fishers may both take risks and manage risk in the context of the physical and biological environment of Bass Strait. In the first instance, skippers who chose to fish on the moon and at a time when the bar was dangerous risked a poor catch in terms of both quantity and quality, and loss of that catch if they could not return to port before it had spoiled. They took a 'calculated risk' which in this case did not pay off but which could be rationalized, as is often the case, as 'that's fishing'. Rule, however, had reduced risk by designing equipment such that he could switch from using one set of gear to another without the need to return to port. To this extent he was risk averse. But the capacity to switch gear was not in itself enough. Rule's choice of shark fishing grounds was not conventional. Indeed, given that prawns disappear as winter advances and water temperature cools, that the seasonal scallop fishery was delayed because relatively high water temperatures earlier in the year had inhibited development of roe, and that shark cannot be located using sonar, Rule's decisions and success were based on particularly subtle knowledge of likely deep water temperatures in particular near-coastal waters.

The knowledge Rule brought to bear in choosing to fish in the way he did, and thereby to ameliorate risks associated with fishing, was the product of 32 years experience as a shark and scallop fisher in local waters. It was knowledge acquired through years of performing as a fisher, knowledge that underwrote his skill as a fisher (e.g. Pálsson 1994). The management of risk in the context of the physical and biological environment of Bass Strait entails, on the one hand, a skipper's judgements concerning the capabilities of his boat, gear and crew and, on the other, his experience as a fisher and the knowledge and skill acquired through that experience. In many circumstances long-term local knowledge may be crucial.

Experience, knowledge and skill underwrite a fisher's engagement with the environment from which he derives his livelihood. It is through that engagement that he constructs identity. And it is by drawing on the particularities of experience, knowledge and skill that he may assert his status as a fisher and his rights to fish (Minnegal et al. 2003). Thus, consideration of decision-making in the context of 'a game against nature' will be always embedded in considerations of, at the least, that orientation to the past which constitutes tradition and that sense of performance which underwrites identity.

\section{Decision-making in the Socioeconomic Environment}

In 2002 the prawn season was interrupted when an algal bloom appeared in the Gippsland Lakes. The bloom was associated with the presence of high levels of the toxin nodularin in some molluscs and crustaceans and, in response, the Victorian Department of Human Services banned harvesting of prawns for human consumption between February 7th and March 1st. The ban covered the waters of the Gippsland Lakes themselves and those of Bass Strait within a 10 kilometre radius of

9. Our sample of shark-fishing trips includes all trips departing from and returning to Lakes Entrance by six dedicated shark boats from February 1 to June 30, 2002. Two trips of one day, and one of two days, in May 2002 are excluded because on these occasions the skippers of the boats concerned had themselves shifted to the "brief and near' strategy. 
the entrance. The ban on harvesting prawns was a source of much concern to ocean fishers at Lakes Entrance. Through the previous two years, and partly in response to poor returns from scallops, an increasing number of fishers had turned to inshore trawling for prawns. Many felt that development of a prawn fishery might ensure a future for the local fleet. In preparation for the 2002 season a number of fishers had made substantial financial commitments in the expectation of good returns. The ban put paid to these aspirations.

Recall that the ban on prawns extended for 10 kilometres in all directions from the Entrance. For a while a few fishers ignored the limit. Some said they sold the prawns as bait. Others whispered that Asians were still buying. A few confused radius with diameter and travelled only 5 kilometres before they shot their net. And one long-established fisher continued to fish within the restricted area but asserted that he had switched target and was not taking prawns. Through this period everyone was watching everyone else. Recreational fishers were watching, lake fishers were watching and other ocean fishers were watching the behaviour of their colleagues. Rumours of inappropriate behaviour by others were common; names were implied but seldom mentioned. The level of tension increased and, as commonly happens when people perceive an external threat to livelihood, the fishers sought unity and potential collective power by establishing the Victorian Ocean Prawners Association (VOPA).

The inaugural meeting of VOPA was held on February 28, 2002. Those who attended moved toward some form of agreement. Irrespective of target, no one would shoot a net within 12 kilometres of the Entrance. This was a voluntary extension of the decreed 10 kilometre limit to both demonstrate responsibility to the public and avoid misreading of a boat's position by recreational fishers who watched from the Lake Tyers hotel and who, it was thought, since they too were not permitted to catch prawns during the ban, would report any misdemeanours by commercial operators. The agreement was to be grounded in trust. The concern was that if anyone cheated, or could be misunderstood as cheating - they fished within the banned area, but not for prawns - then everyone would be penalized. Management might respond to cheating by placing an absolute ban on harvesting prawns by fishers working out from Lakes Entrance, because then enforcement would not be problematic.

One man refused to comply. 'Ned' - a pseudonym - was the owner-skipper of a boat that, for technical reasons, was currently ill-equipped to travel far beyond the entrance. ${ }^{10}$ Through the preceding two weeks he had sometimes fished within the banned area but had not targeted prawns. He stated that this is what he would continue to do, because to comply with the decision of the meeting meant that he, and he alone, could not fish at all. Everyone acknowledged his problem. They congratulated him for publicly acknowledging that he had fished in the restricted area. They gave him moral support but did not retreat from their decision. Ned's problem was not their problem. But his solution to his problem to stay where he was but change his target - was their problem.

It took half an hour before Ned conceded to their demands. He had little other option; to make his living jeopardized everyone else's. Ned contracted to cease fishing for three weeks. He would then return to fishing, though, if the ban was still in place, not for prawns. Coercion won the day. But that coercion was then reconstructed as trust, conflict reshaped as cooperation. The newly elected president of VOPA thanked Ned. There were handshakes. Everyone agreed he was a 'bloody good bloke'. But he was not appeased, and left the meeting. As it happened, his resolve and compliance did not need to be tested because, within a few days of the meeting, the ban was lifted.

In the context of the socioeconomic environment the decisions that fishers make are grounded in understandings, interpretations and manipulations of ever-shifting social interactions. Strategy even cunning - is crucial to acquiring the monetary income which some fishers insist is the 'bottom line'. Each person must judge the possible outcomes of cooperating or competing with fellow fishers, must judge when it is appropriate to trust another fisher, when it is advisable to 'bend the truth' and when coercion may pay dividends. Sometimes it is advisable to 'cut one's losses' and, at least, remain in the game. In the context of this environment a fisher's orientation is strongly toward present circumstances though, of course, his skill in transacting often-changing social and economic circumstances will have been developed through past experience (Andersen 1972; Palmer 1990). The nature of interactions that arise within this context would lend themselves to exploration using the models of game theory. It is important to remember, however, that those models are simplified abstractions and that the extent to which they correspond "to the original phenomenon is always a

10. To minimize the possibility of identifying the fisher concerned we do not report the relevant technical detail. 
matter of judgement and empirical evidence" (Colman and Wilson 1997:25). The explicit value of such models may be in what they reveal about the logical structure of problems that people are called upon to solve and about paradoxes and opportunities that people confront. Their implicit value, as the preceding example illustrates, will be in directing attention to the sorts of interactive adjustments those, for example, entailing trust or bluff - that people may make in attending to those paradoxes and opportunities (Dwyer 2000:232).

\section{Decision-making in the Environment of Management}

Australia's Commonwealth fisheries are managed by the Australian Fisheries Management Authority (AFMA). The often-changing organizational structure of AFMA includes named divisions with primary responsibility over different fisheries that are defined by target or gear (e.g. Bass Strait Central Zone Scallop Fishery, South East Trawl Fishery, Southern Shark Fishery). In January 2001 management of the Australian Commonwealth Southern Shark Fishery (SSF) shifted to output controls. These were based on individual transferable quotas (ITQs; i.e. tradable permits, Tietenberg 2002) in the form of a proportion of an annual total allowable catch (TAC) allocated to each fisher. Determination of an individual's quota was based on catch history in the best three of the four years 1994-97. Quota could be leased or sold without reference to the lessee's or buyer's status as a fisher. Thus, the potential was created for both consolidation of quota either within the hands of a few fishers or within the hands of entrepreneurs without experience as fishers.

Both before, and through, 2001 various concerns emerged regarding the process by which quota was allocated. Some fishers asserted that during the years selected to establish catch history they themselves had spread effort across more than one fishery and, hence, relative to specialist shark fishers had lower returns from shark. They argued that they had been penalized for fishing in ways that contributed to the conservation and sustainability of shark stock (e.g. Hillborn et al. 2001). There were complaints that because, 12 years earlier, input controls (i.e. number and length of nets used) had also been allocated on the basis of catch history, those who now received least quota had, in effect, been doubly penalized. There were complaints that ITQs were not a useful means of managing the shark fishery, that influential fishers had had too much say in the selection of years used to calculate catch history and that some fishers had falsified records to achieve a quota that was higher than their due. Finally, there were complaints that the allocation of quota on the basis of catch history alone failed to take account of the investment in boats, other equipment, time and good will that a fisher had contributed to the industry.

These concerns coincided with a reduction of more than 20 percent in the TAC from 2001 to 2002 and with incorporation of the Southern Shark Fishery within a larger management body in 2003. The ongoing changes generated more paper work and confusion for fishers and, for those operating with large bank loans, little quota or both, concerns about future viability.

In early 2002 two shark fishers challenged decisions of AFMA on the grounds that the method of allocating quota ignored "the transferability of permits and the value attached to permits", a value that was not indicated by reference to catch history alone (Administrative Appeals Tribunal 2002). ${ }^{12}$ Critical evidence concerned the extent to which permits that nominally were not transferable had in fact been transferred for hundreds of thousands of dollars, and the extent to which management had been complicit in these 'under the table' transactions (see Boduguel, 2002, for an analogous Canadian case). The Tribunal found in favour of the applicants on the grounds that the manner in which quota had been distributed had led to a redistribution of wealth. The published decision stated that if AFMA “pursues a policy of TAC \& ITQ's (sic) it should ... regard the permits, at all relevant times as being

11. The potential for ITQs to lead to consolidation of holdings has been widely recognised (e.g. Aslin et al. 2001; McCay 1995; National Research Council 1999) and the realisation of that potential documented elsewhere (e.g. Pálsson and Helgason 1996; Phillips et al. 2002).

12. The institutional separation of a system of permits to fish and of allocated quantities of fish that may be landed (i.e. quota) creates much ambiguity regarding understandings of 'property' and, where different rules apply with respect to rights to trade permits and quota, can create substantial legal and economic complications. Fishers who wish to buy or sell may treat 'permits' and 'quota' - not to mention boats and fishing gear - as a package deal in ways that are inconsistent with some bureaucratic or legal interpretations. Fishers who wish to obtain credit from money lending institutions may find that allocated quota is judged unfavourably as security because, as a proportion of an annually revised total allowable catch, it does not have a guaranteed monetary value. 
transferable" and, further, "in keeping with fairness and equity it would be prudent for fisheries managers to examine the wealth redistribution consequences of alternative allocation formulae". The Tribunal referred the matter of quota allocation back to AFMA for reconsideration.

The decision of the Administrative Appeals Tribunal initiated a lengthy process of legal challenge, review of quota allocation and meetings; 90 written submissions were made by fishers or solicitors and economists acting on behalf of fishers (AFMA 2003a,b; Federal Court of Australia 2003). The Independent Allocation Review Panel, appointed by AFMA, submitted recommendations for the reallocation of quota in November 2003, though assessing the value of ITQs as a management tool was outside their brief (Lockhart and Purcell 2003). The recommendations came into effect in 2004 but, at the time of writing, further legal challenges by fishers are underway.

Both the general tenor of submissions to the review panel, and the specific comments and assertions they contain, were revealing with respect to the mood of participants in the shark fishery as a whole, reflecting ways in which management of that fishery has affected and continues to affect decision-making by fishers, and the personal difficulties experienced by particular fishers. Through the preceding three years we ourselves had been told much of what was revealed in the submissions, often with more passion than is apparent in those submissions. Tales of family breakdown, ill health and exceptional financial difficulty are not uncommon. Over many years some fishers have spent large amounts of money in futile attempts to legally redress what they have judged to be unfair or personally discriminatory. Indeed, some have become almost obsessive with respect to initiating legal action. There is widespread concern with the lack of stability that has arisen from 15 years of almost continual change to management arrangements, change that is unable to be rationalized in terms of a satisfactory scientific understanding of stock and, indeed, seems to many fishers to be unwarranted given a recent conclusion that recruitment of the primary species targeted by SSF fishers - gummy shark - has remained stable for more than 30 years (Bureau of Rural Sciences 2003; see also Anon 2003; Dwyer and Minnegal 2003a,b). ${ }^{13}$ But, most tellingly, dissatisfaction and disunity within the fishery have heightened since the introduction of quotas. As a senior fisher said at one meeting: "before [quota] everyone was equal. But AFMA has treated fishers differently. Now everyone has different amounts of quota. Everyone is measuring themselves against others. 'You have more quota than me, and I hate you"'. He continued by arguing that the introduction of quota was fragmenting the fishing community; that it was undermining cooperation and a sense of equality (Field Notes, July 2003).

In their encounters with management, fishers confront an environment of uncertainty (Kaufmann et al. 1999:81). Indeed, in an important sense, fisheries management in Australia and elsewhere has effectively institutionalized uncertainty. In the first instance, this may be traced to the science of stock assessment that, faced with huge difficulties in accessing satisfactory data, rationalizes 'risk assessment' in terms of the 'precautionary principle', or increasingly turns to analyses based in Bayesian statistics, with the result that "scientific uncertainty and allowable exploitation are coupled" (Degnbol 2003:40; see also Essington 2001; Schmidt 2003). Stated simply, what this means is that legislated decisions about the quantities of fish that fishers may catch appear to be based in what is not known about fish populations. For the fishers whose lives and incomes derive from what they do know about fish populations these recent approaches to fisheries science can appear as a frustrating, logical absurdity. Indeed, in reviewing changes to fisheries science through the past century, Degnbol (2003; see also Roepstorff 2003) reported an increasing separation of that science from the understandings and practices of the fishers themselves. Further, decisions made in the light of the 'precautionary principle' are necessarily oriented toward the future - to outcomes that might be achieved through restraint - but the practice of fishing is always dependent upon past knowledge and present circumstance. ${ }^{14}$ As the

13. Concerns about the status of school shark, Galeorhinus galeus, which are often taken when nets are set for gummy shark (Mustelus species), have contributed to reductions in the TAC for the latter species (AFMA 2003c).

14. Our focus here is with ways in which fishers at Lakes Entrance experience management and not with the understandings or temporal orientations of managers themselves. Again, we note that not all forms of management are necessarily future oriented. ITQ management is a variant of 'postproductivism' in which fishers are constrained by legislation, regulation and enforcement procedures to produce only up to specified amounts of the product in question with the explicit aim of guaranteeing the future sustainability of stock (Evans et al. 2002). Our argument about the ways in which fishers experience ITQ management regimes resonates with Helgason and Pàlsson's (1997) examination of the moral dimensions of the introduction of 'fictitious' commodities in the Icelandic fishing industry and with Ortner's (2005) exploration of "postmodern consciousness as a specific configuration of anxieties, tied in turn to formations of 'late capitalism"”. 
fishers themselves might put it: no one has 'been to, seen or done' the future and, thus, no one has the experience or knowledge to fish on that basis. To this extent, fishers confront a double-bind in which the temporal orientations of engaging with the biophysical environment and with that of management are incompatible and the necessity to attend to both simultaneously is likely to induce frustration and forms of near schizophrenic behaviour.

For fishers, however, an additional complication intrudes in that fisheries management typically fails to extend the reach of the 'precautionary principle' from its potential, though problematic, value as a conservation tool to recognition that that principle "should explicitly incorporate the protection of fishing communities, not only the resources they depend on" (Hillborn et al. 2001:99). ${ }^{15}$ This, perhaps, characterizes much resource management in situations that have shifted from 'modern production' to 'post-production'; from the potential maximization of returns to externally imposed limitation of returns (Dawson 1997; Evans et al. 2002). As Wilson (2002:327-328) wrote with reference to scientific uncertainty and the fishing industry: "we have built into our governing institutions a very particular and inappropriate scientific conception of the ocean that assumes much more control over natural processes than we might hope to have" and, as a result, have "created dysfunctional management institutions". With specific reference to the Australian situation it is of note that AFMA acknowledges the fact of uncertainty but distances itself from any responsibility for that uncertainty. Thus, on different occasions, media releases signed by senior managers have "regretted any disruption or uncertainty that these legal proceedings had caused" but pointed out that delays were due to circumstances beyond AFMA's control and noted that "unfortunately, this review will mean a further period of uncertainty ... but AFMA is left with no choice as we must abide by the court's ... decision" (AFMA 2002, 2003d).

In the context of an often fluctuating market many fishers - especially those who qualify as smaller-scale, life-style fishers - have sought security in diversification. They have invested simultaneously in more than one fishery and, in accordance with their own judgements of current payoffs, switched targets as appropriate. But in the climate of uncertainty that has been created by both the synergisms of fisheries science and fisheries management, and the frequency with which management decisions and structures change, it is precisely these sorts of choices by fishers that are, too often, effectively penalized on the bureaucratic grounds that latent effort within a fishery is inefficient, the fishery is overcapitalized and enforcement is more difficult (Hillborn et al. 2001). We are not surprised, therefore, to observe that in the context of management the behaviour of fishers is sometimes characterized by ironic mirth, uncomprehending rage, letting one's former colleague 'take the bullet first', cheating or 'suing the bastards'. Indeed, with reference to analogous contexts of uncertainty, Picou et al. (2004) have argued that a combination of governmental or organization failure and protracted litigation may contribute to the emergence of 'corrosive communities' whose members experience deteriorating mental and physical health. Decision-making in an environment of uncertainty may often spill over as "irrational exuberance" (Shiller 2000; see also Davis 1991). This is consistent with expectations from game theory under which satisfactory decisions cannot be reached under conditions of uncertainty and the nearest approximation to 'rationality' may be to behave randomly (Colman 1995:23-32,64-66).

\section{Discussion}

In recent writing the social theorists Beck and Giddens have characterized what they variously call late modernity, reflexive modernity or 'risk society' (Beck 1999, Giddens 1999). Their concerns are primarily sociological, not ethnographic, in that they diagnose broad processes implicated in the late modern condition rather than elaborating ways in which people may respond to that condition. The

15. Environmentalists may pay lip service to socioeconomic implications of the 'precautionary principle' but typically prioritize conservation objectives and downplay the close relationship between the viability of fish populations and fishing communities (e.g. Lack et al. 2003; see also Sandberg 1996). Indeed, both environmentalists and scientists may complain that managers are insufficiently attentive to that principle (Lack et al. 2003:49; Tilzey and Rowling 2001:370). Our aim in this article is to report responses by fishers to contexts as they experience them; like many others, including perhaps most managers, we are in no position to assess the validity of judgements concerning stock that are provided by fisheries scientists. Like the fishers themselves, however, and indeed like many scientists, we are aware that error factors in assessing stock are often exceptionally high (e.g. Finlayson 1994). 
identified processes are "globalization, individualization, gender revolution, unemployment and global risks" such as ecological crises and the collapse of financial markets (Beck 1999:2). It is commonalities of uncertainty, of challenges to prior circumstances and doubts regarding future circumstances, that link these processes. The generic responses to the "unforeseen consequences" of these processes are an expectation that future possibilities should guide present actions; the contestation of knowledge claims and authority; and an emphasis upon the self-production of biography. In short, the uncertainties of the present and recent past - the elusive, intangible hazards and threats that appear to jeopardize life on earth - have cut asunder the conventional props of past ways of living and of past ways of attending to change (e.g. Caplan 2000b). As Giddens expressed it, social life has been disembedded from the local (1990; see also Gille and Riain 2002);

A new kind of capitalism, a new kind of social order, a new kind of global order,

a new kind of society and a new kind of personal life are coming into being, all of which differ from earlier phases of social development (Beck 1999:2).

To reinforce, and ground, their diagnoses of the late modern condition Beck and Giddens, to varying degrees, contrast that condition with others that they refer to as 'traditional' (or 'premodern') and 'modern' respectively. For example, in his Reith Lectures, Giddens (1999) contrasted the past orientation of the premodern with the future orientation of the late modern (Giddens 1999:22; see also Beck 1999:137). He depicted a shift in people's understandings of authority - of certainty - from premodern acceptance of the truth value of myth and ritual, through modern trust in the rationality of science, to a late modern state in which all knowledge claims are considered to be in doubt (Giddens 1999:31,41-42; see also Beck 1999:115-116). And he directed attention to the way in which, in premodern situations, a sense of self - of personhood - is "sustained largely through the stability of the social positions of individuals in the community" while in late modern situations it is plastic, and "has to be created and recreated on a more active basis than before" (Giddens 1999:47; see also Beck 1999:9).

To Beck and Giddens, on a global stage, all societies experience the same set of basic challenges but each responds idiosyncratically such that there exist "multiple modernities ... worn in a number of ingeniously different ways" (Beck 1999:3; see also Friedman and Carrier 1996, Knauft 2002). Both theorists rightly oppose the outmoded notion that particular non-Western societies might represent evolutionary precursors to the West. At the same time, however, their writings leave the impression that 'premodern', 'modern' and 'late modern' conditions may be understood as an almost inevitable trajectory that has characterized human history and that characterizes all societies. Both writers tend to universalize and essentialize the emergent configurations of society (Caplan 2000a). Globalization may not be complete, it may follow different paths, but ultimately, for good or bad, it is depicted by these theorists as all-enveloping, as the current or soon-to-be experience of all people in all situations. This is the intent of titles such as 'Runaway World' or 'World Risk Society', of assertions of the emergence of "a global cosmopolitan society" (Giddens 1999:19) or the need for a "cosmopolitan manifesto" (Beck 1999:1).

In Table 1, as an opening gambit, we attempt to capture an essence of the distinctions summarized above. Our initial aim is to depict conventional understandings of ways in which people are thought to 'place' themselves in situations that, broadly speaking, are commonly represented as premodern, modern and late modern respectively. We shall, however, subsequently challenge any implication that these three configurations of understandings stand alone.

With respect to 'certainty' and 'temporal orientation' the snapshot terms we use in Table 1 conform closely to the language of Giddens and Beck. With respect to 'personhood' we have, we think, remained faithful to the intentions of those authors while adopting the language of anthropologists and others. Thus, we employ notions of 'dividual' (or 'partible'), 'individual' and 'cyborg' to denote relational, individualistic and plastic (or machine-like) concepts of personhood in, respectively, premodern, modern and late modern configurations of people (Bird-David 1999; Busby 1997; Haraway 1991; Katz 2003; Strathern 1988).

We have, in addition, borrowed from anthropological writings to depict shifting understandings with respect to social identity and agency. The basis of social identity may be seen as grounded in 'others', in 'self' and in 'things' respectively (e.g. Bamford 1998; Friedman 1994; Giddens 1991). Thus, in the premodern condition actors may be understood to reveal themselves or be revealed through the outcomes of interactions with others; they are embodied in the things and relationships that they produce. In the modern condition actors reveal themselves or are revealed through the outcomes of their personal choices and actions; necessity has given way to existential notions of freedom and 
responsibility. And, in the late modern condition actors reveal themselves or are revealed by the attributes they have come to possess; they embody the things that they consume.

\begin{tabular}{|l||l|l|l|}
\hline Social configurations & Premodern & Modern & Late modern \\
\hline \hline Certainty & myth and ritual & rationality & doubt \\
\hline Social identity & others & self & things \\
\hline Personhood & dividual & individual & cyborg \\
\hline Agency & dialectics of structure & dialectics of strategy & sense of loss \\
\hline Temporal orientation & past & present & future \\
\hline \hline Contexts & Local and 'natural' & Existential & Global and 'artifactual' \\
\hline
\end{tabular}

Table 1. A summary of either conventional representations of 'premodern', 'modern' and 'late modern' social configurations or, more realistically, ways in which people are likely to 'place' themselves in relation to different contexts. See text for explanation.

The bases of agency may be examined initially by reference to the well recognised, but not well resolved, relationship between agency and structure (Giddens 1979; Ortner 1984, 1996). In a largely forgotten article Leach (1962:133) argued that "in all viable systems there must be an area where the individual is free to make choices so as to manipulate the system to his own advantage". With specific reference to the double descent system of Yakö people of West Africa, he showed how individuals might manipulate issues affecting land rights and access to resources and hypothesized "that structural systems in which all avenues of social action are narrowly institutionalized are impossible". Thus, to us, Leach illustrated an ideal premodern condition in which the basis of agency may be understood as grounded in responses to, or possibilities provided by, the dialectics of coexisting, alternative structures or discourses. ${ }^{16}$ But this interpretation is hardly satisfactory when we turn to the modern condition of ephemeral structures and existential selves. Here, it seems, the flux of day to day existence reveals potentials and, at certain times and places, actors may creatively and momentarily draw from those potentials to give shape and meaning to their lives. And here, therefore, the basis of agency may be understood to be often created de novo within the frame of the dialectics of strategy. ${ }^{17}$ Finally, when we turn to the late modern condition much that is written leaves the impression that, with respect to agency, people experience a sense of loss, of bewilderment with regard to a seeming impossibility of choice (see comments by Beck [1999:109] and Giddens [1999:19], concerning the "helplessness" of the individual and the sense of being "in the grip of forces over which we have no control").

At this juncture we return to the fishers of Lakes Entrance, Victoria. Our ethnographic focus on the ways that fishers in a single community make decisions in different contexts directs attention to the multidimensional nature of life worlds and, indeed, to the fact that their experience of, and responses to, those contexts are, in many ways, analogous to the depicted responses of people who live under supposedly premodern, modern and late modern conditions respectively. Thus, in illustrating decisionmaking in the context of the physical and biological environment - a local and 'natural' context - we directed attention to both the pragmatics of managing risk in a dangerous world, to the role of skill, past experience and performance, and to the connections these have to a sense of tradition (Minnegal et

16. Among Kubo people of lowland Papua New Guinea coexisting discourses concerning rights to land are based in, respectively, descent and on-going use. In different circumstances people may invoke one or the other discourse to assert their own rights or to challenge the rights of others (Dwyer and Minnegal 1999, Minnegal and Dwyer 1999).

17. Our argument concerning the basis of agency in the modern condition is in line with Ortner's (1996:12-20) analysis of 'serious games' or 'projects' in which "players are 'agents,' skilled and intense strategizers who constantly stretch the game even as they enact it" and are simultaneously "defined and constructed ... by the game". Indeed, her analyses of, on the one hand, games of status and power in Polynesian societies and, on the other, the game of social mobility in 'modern' (stratified state) society direct attention to opportunities for choice that, in the first case, preexist in the traditional order and, in the second case, may emerge from the fluidity of everyday life. 
al. 2003). We could add too that it is in this context that fishers 'place' themselves in the world by the stories they tell (by their local mythologising of place); by enhancing their sense of security through constructions of 'family' that have a broad reach; by extrapolating from an identity as fishers to a right to fish; by manipulating the associated structural ambiguities of what can be constructed as 'property' (e.g. Zalups 2003); and by ways in which naming and personalizing boats serves to affirm connections with spouses, children, affines and co-fishers (Dwyer et al. 2003). Indeed, with regard to the last, fishers may sometimes understand themselves as being 'dispersed' across the boats with which they have been associated.

Again, in illustrating decision-making in the context of the socioeconomic environment - an 'existential' context - we directed attention to the strategizing of individual actors, to shifting alignments expressed as cooperation or competition and to ways in which fishers might enhance their own interests through opportunistically, and creatively, trusting, bluffing or coercing others. Our emphasis here was with rationality as practical logic and with the immediacy of an actor's decisionmaking in what are often fluid and changing circumstances. We could add too that it is in this context that a fisher judges himself and is judged by others through the outcomes of his own choices and actions; judgements that are expressed in conventional disparagement of environmentalists, scientists and managers as those who have 'never been, never seen, never done' and in measuring the worth of other fishers, irrespective of personal like or dislike, in terms of the quantities of fish that they land (e.g. Pálsson and Helgason 1999; Thorlindsson 1988).

And, finally, in illustrating decision-making in the context of the environment of management an increasingly global and 'artifactual' context - we directed attention to the impasse that is created by the imposition of a future- and globally-oriented scientific and management structure upon a necessarily past-, experientially- and locally-oriented industry. We argued that, to fishers, this, together with frequent changes in management arrangements, contributes to a sense of both lack of stability and loss of control. We could add too that it is in this context that many, though certainly not all, fishers consider that their skill has been devalued and effectively usurped by the technological wherewithal of modern fish-finding; that with respect to both the edicts of management and the power of machines their status is reduced to that of automata; and that the value they once attached to relationships with others with whom they variously cooperated and competed in a spirit of potential egalitarianism has given way to an increasing valorization of money and things and the emergence of inequalities based in either serendipity or skulduggery. In the context of the environment of management, fishers whose experience is represented by these remarks have been relocated conceptually to a 'non-place'.

Thus, reaching out from an initial exploration of the context-dependent ways in which fishers make decisions we have identified significant, and themselves context-related, ways in which fishers 'place' themselves in the world. We have argued, further, that in many respects these ways of 'placement' conform to conventional depictions of predominant and defining features of those social configurations described as 'premodern', 'modern' and 'late modern' respectively. In contexts that might be represented as 'local and natural' the predominant orientations, interests and political manoeuvring of fishers conform in many respects to depictions readily available in accounts of socalled 'premodern' societies (Table 1). And, similarly, in 'existential' and 'global and artifactual' contexts the predominant orientations, interests and political manoeuvring of fishers conform in many respects to depictions available in accounts of, respectively, so-called 'modern' and 'late modern' societies. ${ }^{18}$

There is, here, no universality and no essence in the senses implied by Beck and Giddens. Each fisher is simultaneously engaged with a diversity of contexts and a diversity of understandings of his

18. While appreciating the general thrust of Vayda and Walters' (1999) critique of 'political ecology' we consider that their emphasis upon working "backward in time" reflects their own prioritising of engagement with the biophysical environment as causal and, indeed, of limiting the content of environment to biophysical components alone (Walker 2005). They do not adequately recognise that engagement with other relevant environments may not be amenable to analysis in terms of past events. Nor do they recognise that the biophysical environment itself may be sometimes experienced as uncertain (see footnotes 4 and 5), rendering inappropriate an orientation towards the past in explanations of decision-making. The analytical approach that they advocate, focused as it is on the past, allows too little space for the fact that people's responses to events will be contingent on the understandings they bring to bear on the present contexts in which, for them, the events are situated and the future contexts they seek to shape. 
place in the world. Indeed, our own representations of decision-making were partial in isolating contexts that so-often co-occur. A fisher venturing across the bar, whatever the weather, must contextualize his skill-based decisions about where and how to fish in the frame of others that concern who he can or cannot trust and how he should respond to the recent fax advising yet another change to management arrangements or find the time to both comprehend and answer questions in the latest revision of the authorized log book. On each fishing venture he must balance the demands of skill, cunning and random recklessness; he must balance possibilities that are manifest in the good, the bad and the ugly. ${ }^{19}$ The social theories advocated by Beck and Giddens are incapable of revealing the multi-dimensionality of the lived experience of that fisherman. The lessons, surely, are to appreciate, first, that what holds in general terms for fishers is likely to hold for all communities of people and, secondly, that differences between societies may be best appreciated in terms of the quantitative differences in their constituents' experience of, and exposure to, contexts of different sorts and not in qualitative differences in kinds of people, kinds of history or, indeed, kinds of context.

It is to these ends that Table 1 offers a frame for comparative anthropological analysis. It directs attention to the fact that actors experience contexts of very different sorts and it implies hypotheses concerning the articulation of those contexts with ways of being in the world. But some cautionary remarks are needed. It is likely, we suggest, that elements of all identified contexts are experienced at some times and some places in all societies of people. That is, there is no intended implication in our analyses of Victorian fishers that understandings appropriate to 'local and natural' contexts merely qualify as vestiges from the past or as grounds for nostalgic longing. Nor do we think that the sorts of understandings appropriate to 'existential' or 'global and artifactual' contexts merely qualify as historical accretions to the 'natural'. Rather, the frame we have offered allows that people may simultaneously experience multiple contexts but that biases will occur in predominant contexts and, hence, in ways in which people express understandings of their 'place' in the world. ${ }^{20}$ Unfortunately, within anthropology, conventional methodologies and theoretical biases are predisposed to represent quantitative emphasis as qualitative difference and, thereby, both understate commonalities of human experience and fail to appreciate that apparent transformations in social life may be initiated by rereading that which preexisted in the light of new experience (Minnegal and Dwyer 1999).

Finally, we should broaden the reach of our remarks concerning ways in which people may or do respond to circumstances that Beck and Giddens diagnose as 'late modernity' and that we identify as 'global and artifactual' contexts. Both Beck and Giddens assert that their understandings of late modernity are optimistic and, indeed, serve to counter the angst, deconstruction and nostalgia implicit in much of the postmodernist critique of modernity. Postmodernism may identify uncertainties; late or reflexive modernity provides opportunities to come to terms with them. They argue that the uncertainties of the present may be reduced - in our terms converted to quantifiable risks - by increases in knowledge, by globalization in all its guises and by 'democratizing' institutions in ways that increase awareness and empower actors. In effect, uncertainty may be understood as a 'local'

19. When different environments come into conjunction practical logic may, of necessity, entail that orientations shift between them rather than that a single orientation will dominate. The complex nature of decision-making in such circumstances means the strategies that inform particular decisions can be elucidated only through empirical investigation. From a theoretical perspective, however, the intent of "drama theory", itself a recent development from game theory, may be instructive. Drama theory is based on the "idea that games are not static, one shot deals decided by rationality, but dynamic situations that can be utterly transformed by the emotions of the players" (Matthews 1998:29; see also Howard 1994, Bryant 1997). It accommodates the facts that actors may transform the game in the course of an engagement and that the 'rules of play' are contingent upon circumstances of the moment.

20. Generic examples are provided by, first, the diversity of exchange systems found in many so-called 'traditional' societies where, in different but co-occurring contexts, predominant persuasions and correlated understandings may concern either 'gifts' or 'commodities' and, secondly, by the co-occurrence in many Melanesian societies of understandings and practices that, in earlier literature, were considered diagnostic of 'Big Man' and 'Great Man' societies respectively (e.g. Bohannan 1955; Godelier and Strathern 1991; Gregory 1982; Toren 1989). A more particular example is provided by Baktaman of Papua New Guinea where sacred knowledge is transmitted from older to younger males in the course of a life-long series of initiations that progressively create an understanding that certainty is in doubt (Barth 1975). In as much as sacred knowledge reaches beyond the secular, and originates from a domain that is not 'natural', so the context in which these Baktaman understandings exist may be regarded, from their perspective but in our language, as 'global and artifactual'. 
problem that may be ameliorated by enlarging one's horizons. Thus, the experience of uncertainty becomes relativized; it is a matter of scale.

There are several problems here. By no means the least of these are the complications entailed where, as we have argued for fisheries management, uncertainty has been built into policy but its impacts flow out from the institution and are not felt internally. The managers and those they manage occupy different conceptual positions with respect to risk and uncertainty and both institutional inertia and incompatible world views inhibit communication and 'democratizing' change (e.g. Roepstorff 2003). ${ }^{21}$ In addition, to the extent that the experience of uncertainty is an outcome of perceived effects of the 'global' on the 'local' so too, for the participants, potential resolution to problems that may be provided by an increase in scale - by incorporation within a more global world - must be temporary. The logic of late modernity (of reflexion) is that problems will emerge at the new scale and a further increase in scale will be necessary to alleviate those problems. Ultimately, of course, a limit will be reached in which globalization is complete, all the world is 'objectified' and the only hope for 'subjective security' may be, almost literally, to reach for the stars. ${ }^{22}$ And, thirdly, to re-ground our remarks in ethnographic realities, for people whose modes of production are necessarily reliant on past experience, current performance and acquired skill, and whose opportunities to shape the world are given by manipulation of tangible and immediate relationships within which they are embedded, the uncertainties that arise through enforced exposure to extrinsic demands and structures - to the totalizing abstractions of 'global and artifactual' contexts (Hornborg 1996) - will be always problematic.

\section{References Cited}

Adams, J.

"Cars, cholera, and cows: The management of risk and uncertainty." Policy Analysis No. 335. Washington, DC: Cato Institute, 1999.

Administrative Appeals Tribunal

Fischer and Australian Fisheries Management Authority [2002] AATA 857 (27 September 2002). Canberra: Commonwealth of Australia, 2002.

Andersen, R.

"Hunt and Deceive: Information Management in Newfoundland Deep-sea Trawler Fishing." In North Atlantic Fishermen: Anthropological Essays on Modern Fishing, edited by R. Andersen and C. Wadel, 120-40. Toronto: University of Toronto Press, 1972.

Anon

"A Fisherman Dispossessed: Michael Hobson on Myths, MPAs and Quotas.” Fishing Today 16 (2003):31-3.

Aslin, H., R. Connor and M. Fisher

Sharing the Catch or Cashing in the Share? Individual Transferable Quotas and the South East Fishery. Canberra: Bureau of Rural Sciences, 2001.

Australian Fisheries Management Authority

AFMA to Challenge Administrative Appeals Tribunal Decision on Allocation of Shark Quota. Media Release, 23 October 2002. Canberra: Commonwealth Government of Australia, 2002.

Public Submissions Received re Independent Review of Quota Allocation for School and Gummy Shark in the Southern Shark Fishery; 1 August 2003. http://www.afma.gov.au, 2003a [Accessed August 4, 2003].

21. The literature on fisheries is replete with recommendations concerning comanagement and institutions of fisheries management routinely allow for input from industry by including 'Comanagement Councils', 'Management Advisory Committees', or analogous bodies, at some level of the hierarchical organization (Dubbink and van Vliet 1996; Healey and Hennessey 1998; Hønneland 1999; Jentoft et al. 1999). There is, however, little evidence that successful outcomes are often achieved for the majority of fishers. In part, this is because social concerns are regarded as intangible, or personal, and are soon dismissed as discussion increasingly focuses upon, as we heard one judge say, the pragmatic and relevant issues of economics and the status of stock (e.g. Paredes 1985). In our experience nearly all stakeholders are complicit in reshaping the content of that which is taken to be relevant.

22. In a similar vein, Giddens (1999:48-50) sees "fundamentalism" as "a child of globalisation" and as a particular form of inward- or backward-looking response that contributes to the sense of security of participants. 
Second Round of Public Submissions Received re Independent Review of Quota Allocation for School and Gummy Shark in the Southern Shark Fishery; 21 August 2003. http://www.afma.gov.au, 2003b [Accessed August 25, 2003].

- Southern Shark Fishery. Independent Allocation Review Panel: Factual brief. Canberra: Commonwealth of Australia, 2003c.

AFMA to Review Allocation of Shark Quota. Media Release, 25 March 2003. Australian Bamford, S Fisheries Management Authority, Commonwealth Government of Australia, 2003d.

"Segmentary Opposition and the Theory of Games: A study of Pathan Organization." Journal of
the Royal Anthropological Institute of Great Britain and Ireland $89(1959) \cdot 5-21$ "Humanized Landscapes, Embodied Worlds: Land and the Construction of Intergenerational Continuity among the Kamea of Papua New Guinea.” Social Analysis 42 (1998):28-54. the Royal Anthropological Institute of Great Britain and Ireland 89 (1959):5-21.

Ritual and Knowledge among the Baktaman of New Guinea. New Haven: Yale University Beck, U. Press, 1975.

World Risk Society. Cambridge: Polity Press, 1999.

Bird-David, N.

"“Animism' Revisited: Personhood, Environment, and Relational Epistemology." Current Anthropology 40 (1999):S67-S91.

Bodiguel, C.

"Fishermen Facing the Commercial Lobster Fishery Licencing Policy in the Canadian Maritime Provinces: Origins of Illegal Strategies, 1960-2000.” Marine Policy 26 (2002):271-81.

Bohannan, $\mathrm{P}$.

"Some Principles of Exchange and Investment among the Tiv." American Anthropologist 57

Bourdieu, P. (1955):60-70

Bryant, J.

The Logic of Practice. Oxford: Polity Press, 1990.

"The Plot Thickens: Understanding Interaction through the Metaphor of Drama." Omega, International Journal of Management Science 25 (1997):255-66.

Bureau of Rural Sciences Fisheries Status Reports 2002-2003. Australian Commonwealth Government.

Busby, C. http://www.brs.gov.au, 2003 [Accessed 10 March 2004].

"Permeable and Partible Persons: A Comparative Analysis of Gender and Body in South India and Melanesia." The Journal of the Royal Anthropological Institute (N.S.) 3 (1997):261-78.

Caplan, P. (Ed.)

Risk Revisited. London: Pluto Press, 2000a.

"Introduction: Risk Revisited." In Risk Revisited, edited by P. Caplan, 1-29. London: Pluto Press, 2000b.

Cashdan, E. A. (Editor)

Risk and Uncertainty in Tribal and Peasant Economies. Boulder: Westview Press, 1990.

Colman, A. M.

Game Theory and its Applications in the Social and Biological Sciences. London: Butterworth.

Colman, A. and C. Wilson

"Antisocial Personality Disorder: An Evolutionary Game Theory Analysis." Legal and Criminological Psychology 2 (1997): 23-34.

Colman, A. M. and C. Wilson

"Antisocial Personality Disorder: An Evolutionary Game Theory Analysis." Legal and Criminological Psychology 2 (1997):23-34.

Davenport, W.

Jamaican Fishing: A Game Theory Analysis. Yale University Publications in Anthropology 59

Davis, A. (1970):3-11.

"Insidious Rationalities: The Institutionalisation of Small Boat Fishing and the Rise of the Rapacious Fisher.” Maritime Anthropological Studies 4 (1991):13-31. 
Dawson, A.

"Identity and Strategy in Post-production Agriculture: A Case Study from Northern Ireland." In Culture and Policy in Northern Ireland: Anthropology in the Public Arena edited by H. Donnan and G. McFarlane, 37-58. Belfast: Institute of Irish Studies, Queen's University of Belfast, 1997.

Degnbol, P.

"Science and the User Perspective - The Gap Co-management Must Address." In The Fisheries Co-management Experience: Accomplishments, Challenges and Prospects edited by D. C. Wilson, J. R. Nielsen and P. Degnbol, 31-50. Kluwer Academic Publisher: Kluwer Academic Publisher, 2003.

Douglas, M. and A. Wildavsky

Risk and Culture: An Essay on the Selection of Technical and Environmental Dangers. Berkeley: University of California Press, 1982.

Dubbink, W. and M. van Vliet

"Market Regulation versus Co-management? Two Perspectives on Regulating Fisheries Compared." Marine Policy 20 (1996):499-516.

Dugatkin, L. A.

Cooperation among Animals: An Evolutionary Perspective. New York: Oxford University Press, 1996.

Dwyer, P. D.

"Mamihlapinatapai: Games People (might) Play." Oceania 70 (2000):231-51.

Dwyer, P. D., R. Just and M. Minnegal

A Sea of Small Names: Fishers and their Boats in Victoria, Australia. Anthropological Forum $13(2003): 5-26$.

Dwyer, P. D. and M. Minnegal

The Transformation of Use Rights: A Comparison of two Papua New Guinean Societies. Journal of Anthropological Research 55 (1999):361-83.

Social Dimensions of Commercial Fisheries: Some Implications for Management. Submission to Australian Fisheries Management Authority in response to the discussion paper 'Changing Directions for AFMA'; November 3, 2003, 2003a.

"Social Dimensions of Commercial Fisheries - Some Implications for Management." Professional Fisherman 26 (2003b):20.

Essington, T. E.

"The Precautionary Approach in Fisheries Management: The Devil is in the Details." Trends in Ecology \& Evolution 16 (2001):121-22.

Evans, N., Morris, C. and Winter, M.

"A Critique of Postproductivism as the New Orthodoxy." Progress in Human Geography 26 (2002): 313-32.

Federal Court of Australia Australian Fisheries Management Authority v Graham [2003] FCA 231 (24 March 2003).

Finlayson, A. C.

Fishing for Truth: A Sociological Analysis of Northern Cod Stock Assessments from 1977 to 1990. Newfoundland: ISER Publications, 1994.

Friedman, J.

"Introduction." In Consumption and Identity edited by J. Friedman, 1-22. Chur, Switzerland: Harwood Academic Publishers, 1994.

Friedman, J. and J. G. Carrier (Editors)

Melanesian Modernities. Lund Monographs in Social Anthropology No. 3. Lund, Sweden: Lund University Press, 1996.

Giddens, A.

Central Problems in Social Theory: Action, Structure and Contradiction in Social Analysis. Cambridge: Cambridge University Press, 1979.

Modernity and Self Identity: Self and Society in the Late Modern Age. Stanford, California: Stanford University Press, 1991

Conversations with Anthony Giddens: Making Sense of Modernity (Anthony Giddens and Christopher Pierson). Cambridge: Polity Press, 1998. 1999 . 
Gille, Z. and S. Ó Riain

"Global Ethnography." Annual Reviews of Sociology 28 (2002):271-95.

Godelier, M. and M. Strathern (Editors.)

Big Men and Great Men: Personifications of Power in Melanesia. Cambridge: Cambridge University Press, 1991.

Gregory, C. A.

Gifts and Commodities. London: Academic Press, 1982.

Haraway, D. J.

Simians, Cyborgs, and Women: The Reinvention of Nature. New York: Routledge, 1991.

Harris, $M$

The Rise of Anthropological Theory: A History of Theories of Culture. New York: Thomas Y. Crowell Company, 1968.

Hawkes, K.

"Why do Men Hunt? Benefits for Risky Choices." In Risk and Uncertainty in Tribal and Peasant Economies edited by . Edited by E. A. Cashdan, 145-66. Boulder: Westview Press, 1990.

"Sharing and Collective Action." In Evolutionary Ecology and Human Behavior edited by E. A. Smith and B. Winterhalder, 269-300. New York: Aldine de Gruyter, 1992.

Healey, M. C. and T. Hennessey

"The Paradox of Fairness: The Impact of Escalating Complexity on Fishery Management." Marine Policy 22 (1998):109-18.

Helgason, A. and G. Pàlsson

"Contested Commodities: The Moral Landscape of Modernist Regimes." Journal of the Royal Anthropological Institute (N.S.) 3 (1997): 451-71.

Hilborn, R., J-J. Maguire, A. M. Parma and A. A. Rosenberg

"The Precautionary Approach and Risk Management: Can they Increase the Probability of Successes in Fishery Management?" Canadian Journal of Fisheries and Aquatic Sciences 58 (2001):99-107.

Hønneland, G.

"Co-management and Communities in the Barents Sea Fisheries." Human Organization 58 (1999):397-404.

Hornborg, A.

"Ecology as Semiotics: Outlines of a Contextualist Paradigm for Human Ecology." In Nature and Society: Anthropological Perspectives edited by P. Descola and G. Pálsson, 45-62. London: Routledge, 1996.

Howard, N.

"Drama Theory and its Relation to Game Theory. Part 1: Dramatic Resolution vs. Rational Solution." Group Decision and Negotiation 3 (1994):187-206.

Jentoft, S. B. J. McCay and D. C. Wilson

"Social Theory and Fisheries Co-management." Marine Policy 22 (1998):423-36.

Kahneman, D. and A. Tversky (Editors)

Choices, Values, and Frames. Cambridge: Cambridge University Press, 2000.

Kaplan, H., K. Hill and A. M. Hurtado

"Risk, Foraging and Food Sharing among the Ache." In Risk and Uncertainty in Tribal and Peasant Economies edited by E. A. Cashdan, 107-43. Boulder: Westview Press, 1990.

Katz, J. E. (Editor)

Machines that Become Us: The Social Context of Personal Communication Technology. New Brunswick, N.J.: Transaction Publishers, 2003.

Kaufmann, B., G. Geen and S. Sen

Fish Futures: Individual Transferable Quotas in Fisheries. Kiama, NSW: Fisheries Research and Keynes, J. M Development Corporation and Fisheries Economics, Research and Management Pty Ltd, 1999.

King, T. J. “The General Theory of Employment.” Quarterly Journal of Economics 51 (1937):209-23.

"Crisis of Meanings: Divergent Experiences and Perceptions of the Marine Environment in Victoria, Australia." The Australian Journal of Anthropology 16 (2005):350-65. 
Knauft, B. M. (Editor) Critically Modern: Alternatives, Alterities, Anthropologies. Bloomington: Indiana University Press, 2002.

Knight, F. H. Risk, Uncertainty and Profit. Boston: Houghton Mifflin Company, 1933 [1921].

Lack, M., K. Short and A. Wilcock Managing Risk and Uncertainty in Deep-sea Fisheries: Lessons from Orange Roughy. Sydney: Leach, E. TRAFFIC Oceania and WWF Australia, 2003.

"On Certain Unconsidered Aspects of Double Descent Systems." Man 62 (1962):130-34.

Lockhart, J. and D. Purcell Independent Allocation Review Panel for the Southern Shark Fishery. Final Report to the Australian Fisheries Management Authority. www.afma.gov.au, 2003. [Accessed October 17, 2003.]

Ludvico, L. R., I. M. Bennett and S. Beckerman "Risk Sensitive Foraging Behavior among the Barì." Human Ecology 19 (1991):509-16.

Matthews, R. "Don't Get Mad, Get Even." New Scientist 160 (1998):26-31.

Maynard Smith, J. Evolution and the Theory of Games. Cambridge: Cambridge University Press, 1982.

McCay, B. J. "Social and Ecological Implications of ITQs: An Overview." Ocean \& Coastal Management 28 (1995):3-22.

Minnegal, M. and P. D. Dwyer

"Re-reading Relationships: Changing Constructions of Identity among Kubo of Papua New Guinea." Ethnology 38 (1999):59-80.

Minnegal, M., T. J. King, R. Just and P. D. Dwyer

"Deep Identity, Shallow Time: Sustaining a Future in Victorian Fishing Communities." The Australian Journal of Anthropology 14 (2003):53-71.

National Research Council Sharing the Fish: Toward a National Policy on Individual Fishing Quotas. Committee to

Ortner, S. B. Review Individual Fishing Quotas. Washington, DC: National Academy Press, 1999.

"Theory in Anthropology since the Sixties." Comparative Studies in Society and History 26 (1984):126-66.

Making Gender: The Politics and Erotics of Culture. Boston: Beacon Press, 1996.

Palmer, C. T. "Subjectivity and Cultural Critique". Anthropological Theory 5 (2005): 31-52.

"Balancing Competition and Cooperation: Verbal Etiquette among Maine Lobstermen." Pálsson, G. Maritime Anthropological Studies 3 (1990):87-105.

"Enskilment at Sea." Man (N.S.) 29 (1994):901-27.
Pálsson, G. and A. Helgason

"Property Rights and Practical Knowledge: The Icelandic Quota System." In Fisheries Management in Crisis edited by K. Crean and D. Symes, 45-60. Oxford: Fishing New Books, 1996.

— "Schooling and Skipperhood: The Development of Dexterity." American Anthropologist 101 (1999):908-23.

Paredes, J. A.

"Any Comments on the Sociology Section, Tony?': Committee Work as Applied Anthropology in Fishery Management." Human Organization 44 (1985):177-82.

Phillips, G., L. Kriwoken and P. Hay

"Private Property and Public Interest in Fisheries Management: The Tasmanian Rock Lobster Fishery." Marine Policy 26 (2002):459-69.

Picou, J. S., B. K. Marshall and D. A. Gill

"Disaster, Litigation, and the Corrosive Community." Social Forces 82 (2004): 1493-522. 
Pike, K. Language in Relation to a Unified Theory of the Structure of Human Behavior, Vol. 1. Glendale: Summer Institute of Linguistics, 1954.

Roepstorff, A.

"Clashing Cosmologies: Contrasting Knowledge in the Greenlandic Fishery." In Imagining Nature: Practices of Cosmology and Identity edited by A. Roepstorff, N. Bubandt and K. Kull, 117-42. Langelandgade, Denmark: Aarhus University Press, 2003.

Sandberg, A.

"Community Fishing or Fishing Communities." In Fisheries Management in Crisis edited by K. Schmidt, K Crean and D. Symes, 34-42. Oxford: Fishing New Books, 1996.

Shiller, R. J. "The Big Catch." New Scientist 177 (2003):42-5.

Smith, E. A. Irrational Exuberance. Princeton: Princeton University Press, 2000.

"Risk and Uncertainty in the 'Original Affluent Society': Evolutionary Ecology of Resourcesharing and Land Tenure." In Hunters and Gatherers 1: History, Evolution and Social Change edited by T. Ingold, D. Riches and J. Woodburn, 222-52. New York: Berg, 1991.

Smith, V. L.

Bargaining and Market Behavior. Cambridge: Cambridge University Press, 2000.

Strathern, M.

The Gender of the Gift: Problems with Women and Problems with Society in Melanesia. Los Angeles: University of California Press, 1988.

Thorlindsson, $\mathrm{T}$.

The Skipper Effect in the Icelandic Herring Fishery." Human Organization 47 (1988):199-212.

Tietenberg, $\mathrm{T}$.

"The Tradable Permits Approach to Protecting the Commons: What have we Learned?" In The Drama of the Commons edited by E. Ostrom, T. Dietz, N. Dolšak, P. C. Stern, S. Stonich and E. U. Weber, 197-232. Washington, DC: National Academy Press, 2002.

Tilzey, R. D. J. and K. R. Rowling

"History of Australia's South East Fishery: A Scientist's Perspective." Marine and Freshwater Toren, C. Research 52 (2001):361-75.

"Drinking Cash: The Purification of Money in Ceremonial Exchange in Fiji." In Money and the Morality of Exchange edited by J. Parry and M. Bloch, 142-64. Cambridge: Cambridge University Press, 1989.

Vayda, A. P. and B. B. Walters

"Against Political Ecology.” Human Ecology 27 (1999):167-79.

Walker P. A.

"Political Ecology: Where is the Ecology?" Progress in Human Geography 29 (2005):73-82.

Wilson, J.

"Scientific Uncertainty, Complex Systems, and the Design of Common-pool Institutions." In The Drama of the Commons edited by E. Ostrom, T. Dietz, N. Dolŝak, P. C. Stern, S. Stonich, and E. U. Weber, 327-59. Washington, DC: National Academy Press, 2002.

Wisner, B., P. Blaikie, T. Cannon and I. Davis

At Risk: Natural Hazards, People's Vulnerability and Disasters. London: Routledge, 2003. Zalups, M.

"Fishing Rights and Private Property." Professional Fisherman 26 (2003):16-7. 


\begin{abstract}
In this paper, decision-making by Australian commercial fishers is explored with reference to aspects of risk or uncertainty that characterize their experience of the physical and biological environment, the socioeconomic environment and the environment of management. In these environments decisions are grounded in, respectively and particularly, skill, strategy and (often) recklessness. In a broader frame it is argued that ways in which fishers 'place' themselves in these distinct environments with respect to certainty, social identity, personhood, agency and temporal orientation have parallels with conventional anthropological and sociological representations of 'premodern', 'modern' and 'late modern' societies respectively. Our argument directs attention to the multidimensional life-worlds of fishers and serves as an ethnographically-based critique of the universalizing and essentializing themes of some recent approaches in social theory.
\end{abstract}

Key Words: risk, uncertainty, decision-making, commercial fishing, management, late modernity, Australia.

\title{
Résumé
}

L'article se propose d'analyser le processus de prise de décision par les pécheurs professionnels australiens en rapport avec les risques ou incertitudes qui caractérisent leur expérience des milieux physique et biologique ainsi que de l'environnement socio-économique et celui de la gestion de l'entreprise. Dans ces milieux les décisions sont fondées respectivement et de façon particulière sur la compétence, la stratégie et (souvent) l'imprudence ou la témérité. Dans un cadre plus large on tente de montrer que les façons dont les pécheurs se « placent » dans ces différents milieux quant à la notion de certitude, de situation sociale, d'identité, d'intermédiation et d'orientation temporelle présentent des similitudes respectivement avec les représentations anthropologiques et sociologiques traditionnelles des sociétés "pré-modernes », " modernes » et "modernes-contemporaines ». Notre argumentation attire l'attention sur les mondes multidimensionnels des pécheurs et sert de critique ethnographique des thèmes universalistes et essentialistes que l'on rencontre dans certaines approches récentes en matière de théorie sociale.

Mots clès: risques, incertitude, prise des décisions, pécheurs professionnels, gestion de l'entreprise, modernité contemporaine, l'Australie.

\section{Resúmen}

Este artículo explora el proceso de toma de decisiones entre pescadores comerciales australianos con respecto al riesgo e incertidumbre que caracteriza su experiencia de los medioambientes físico, biológico, socioeconómico y administrativo. En estos medioambientes las decisiones están basadas, respectiva y particularmente, en competencias, estrategias y (frecuentemente) la imprudencia. En un contexto más amplio, el artículo argumenta que las formas en las que los pescadores se ubican a sí mismos en estos diversos medioambientes con respecto a la certidumbre, su identidad social, su identidad personal, su agentividad y su orientación temporal tienen paralelos en representaciones antropológicas y sociológicas convencionales de sociedades 'premodernas', 'modernas' y de la 'modernidad tardía' respectivamente. Nuestro argumento llama la atención a los multidimensionales mundos de la vida (Lebenswelt) de los pescadores y sirve como una crítica etnográficamente fundada sobre temas universalistas y esencialistas de algunas propuestas recientes en teoría social.

Palabras clave: riesgo, incertidumbre, toma de decisiones, pesca comercial, administración, modernidad tardía, Australia. 